\title{
BASIN-CENTERED GAS SYSTEMS OF THE U.S. PROJECT DE-AT26-98FT40031
}

\author{
U.S. Department of Energy, Federal Energy Technology Center \\ Contractor: U.S. Geological Survey Central Region Energy Team
}

\section{Quarterly Report for April-June, 1998}

\section{SCOPE}

The scope of this project identifies, and characterizes the geologic and geographic distribution of basin-centered gas systems throughout the U.S., including Alaskî. This project risks and ranks the basin-centered gas systems, and for selected systems estimates the location of "sweet spots" where basin-centered gas resources are likkely to been produced over the next 30 years. This project covers a twenty-four (24) month period $\vec{\Sigma}$ of performance; twelve months for Phase I (April, 1998 through March, 1999) and twelve months for Phase II (April, 1999 through March, 2000).

\section{OBJECTIVE}

The principal objective of this project is to perform an analysis of basin-centered gas occurrence in the U.S. and analyze its potential significance to future natural gas exploration and development. This project shall utilize state-of-the-art procedures and knowledge of basin-centered gas systems, including, stratigraphic analysis, organic geochemistry, basin thermal dynamics and reservoir and pressure analyses. All information will be stored in database format, and products will be fully digital.

\section{TASKS:}

Phase I (April, 1998 through March, 1999).

The USGS shall conduct a National inventory of known basin-centered gas systems, define new potential systems, rank them according to levels of geologic certainty, further delineate their geologic and geographic characteristics, and produce a map showing their distribution throughout the U.S.

Task No. 1--April, 1998 through March, 1999 Conduct a National inventory of known basin-centered gas systems and produce a map showing geographic location, and supporting documentation of their stratigraphic location and geologic characteristics.

\section{April-June accomplishments:}

For the period April-June, 1998, project personnel have been conducting literature searches and compiling pertinent information on potential basin-centered gas systems and have begun to fill out the criteria form and write geologic characterizations. Information we continue focusing our efforts on includes: absence of a downdip water contact; 
absence of obvious traps and seals; cross-cutting of lithologic and stratigraphic boundaries; low matrix permeabilities of reservoirs; abnormal pressures; and association with good source rocks. During this quarter, geologic information has been gathered on fifteen (15) basins or areas. At least fifteen (15) other areas have been identified as being basin-centered accumulations, and we are pursuing compiling geologic and engineering data for those.

Task No. 2--April, 1998 through March, 1999

Re-examine basins and other areas throughout the U.S. that were previously defined as conventional accumulations, and determine if they might have been mis-classified. If it is determined that these basins or areas exhibit characteristics that could be consistent with those of basin-centered gas systems, maps of their location and supporting geologic documentation will be provided.

\section{April-June accomplishments:}

For the period April-June, 1998, project personnel have been reviewing the geology and production characteristics of basins and plays that were defined as conventional in the 1995 USGS National Assessment to see if they were mis-classified. We are continuing to collect geologic and engineering information on these basins and plays to determine if they might be considered basin-centered gas accumulations. Excel spreadsheets, compiling critical data are currently being prepared for these basins and plays. The spreadsheets will allow us to manipulate the data and perform statistical analyses. We also have been examining geophysical logs for selected areas to determine porosity and permeability ranges, and possible identification of abnormal pressures.

Task No. 3--October, 1998 through March, 1999

Risk and rank the newly created list of basin-centered gas systems according to levels of geologic certainty. The USGS shall prepare a Topical Report detailing the Phase I activities. The report shall include a digital map showing all defined basin-centered gas systems for the U.S. and documentation of their geologic characteristics.

Once we have created the list of basin-centered gas systems for the U.S. we will proceed with this task. 


\section{DISCLAIMER}

This report was prepared as an account of work sponsored by an agency of the United States Government. Neither the United States Government nor any agency thereof, nor any of their employees, make any warranty, express or implied, or assumes any legal liability or responsibility for the accuracy, completeness, or usefulness of any information, apparatus, product, or process disciosed, or represents that its use would not infringe privately owned rights. Reference herein to any specific commercial product, process, or service by trade name, trademark, manufacturer, or otherwise does not necessarily constitute or imply its endorsement, recommendation, or favoring by the United States Government or any agency thereof. The views and opinions of authors expressed herein do not necessarily state or reflect those of the United States Government or any agency thereof. 


\section{DISCLAIMER}

\section{Portions of this document may be illegible in electronic image products. Images are produced from the best available original document.}

